\title{
DETERMINAN MOTIVASI KERJA SERTA IMPLIKASINYA TERHADAP KINERJA KARYAWAN PADA PT. INNOVATIVE PLASTIC PACKAGING KARAWANG PLANT
}

\author{
Asep Saepudin \\ Universitas Singaperbangsa Karawang \\ Fakultas Ekonomi dan Bisnis Program Studi Magister Manajemen \\ Email : asepsaepudin0664@gmail.com
}

\begin{abstract}
The problem raised in this research is to know, analyze and review the training, compensation, motivation and performance of employees at PT.Innovative Plastic Packaging Karawang plant. Analyze and prove the effect of training and compensation on motivation partially and simultaneously, analyze and prove the influence of motivation on employee performance. As well as analyzing and proving the effect of training, compensation partially and simultaneously on employee performance through motivation.

This study uses path analysis, with the number of samples taken as much as 80 respondents with saturated sampling technique. The research method used in this research by using descriptive method and verifikatif.

From the results of analysis of research data obtained some conclusions as follows: (1) Employee performance (Z) is in the range of good scale. Where the indicator of conformity of tasks with work procedures obtained the highest score, while satisfaction on the work obtained the lowest score. (2) Motivation (Y) is in the range of a good scale. Where the peer assistance indicators get the highest score, while the achievement award gets the lowest score. (3) Training $\left(\mathrm{X}_{1}\right)$ is on a good scale range. Where the cost advantage training indicator scores get the highest score, while the training material indicator scores the lowest. (4) Compensation $\left(\mathrm{X}_{2}\right)$ is in the range of a good scale. Where employment status indicators get the highest score, while the profit bonus indicator companies get the lowest. (5) Training $\left(\mathrm{X}_{1}\right)$ have a significant effect on motivation $(\mathrm{Y})$, with $\mathrm{t}$ test criterion 2.617> t table 1.991. Compensation $\left(\mathrm{X}_{2}\right)$ have a significant effect on the motivation with the criterion t test 7.349

$>$ t table 1.991 . Training $\left(\mathrm{X}_{1}\right)$, compensation $\left(\mathrm{X}_{2}\right)$ simultaneously affect the motivation (Y) with the test criteria F arithmetic 95.20> F table 2.72. (6) Motivation (Y) has a significant

effect on employee performance with the test ktiteria t-test 13.349> t-table 1.991. (7) Training $\left(\mathrm{X}_{1}\right)$ has no significant effect on employee performance (Z) with the criterion of $t$ test count 1,872 <from t-table 1,991 . Compensation $\left(\mathrm{X}_{2}\right)$ has no significant effect on

employee performance $(Z)$ with the criterion of $t$ test count $1,872<$ from $t$ table 1.991. Training $\left(\mathrm{X}_{1}\right)$, compensation $\left(\mathrm{X}_{2}\right)$ and motivation $(\mathrm{Y})$ have a significant effect on employee performance $(\mathrm{Z})$ with $\mathrm{F}$ test criterion $251.777>2.72$
\end{abstract}

Keywords: Employee Performance, Motivation, Training, Compensation 


\section{PENDAHULUAN}

Pembangunan ketenagakerjaan bertujuan untuk memberdayakan dan mendayagunakan tenaga kerja secara optimal dan manusiawi, mewujudkan pemerataan kesempatan kerja dan penyediaan tenaga kerja yang sesuai dengan kebutuhan pembangunan nasional dan regional, memberikan perlindungan kepada tenaga kerja dalam

mewujudkan kesejahteraan, serta meningkatkan kesejahteraan tenaga kerja dan keluarganya. Pembangunan ketenagakerjaan mempunyai banyak dimensi dan keterkaitan, keterkaitan itu tidak hanya dengan tenaga kerja, tetapi juga keterkaitan dengan kepentingan perusahaan, pemerintah dan masyarakat. Untuk itu diperlukan pengelolaan yang bersifat komprehensif, antara lain mencakup pengembangan sumberdaya manusia, terpenuhinya hak - hak dan perlindungan yang mendasar bagi tenaga kerja, peningkatan kualitas , produktifitas, kinerja dan daya saing tenaga kerja, serta pada saat yang bersamaan dapat mewujudkan kondisi yang kondusif bagi kelangsungan dan pengembangan dunia usaha.

Menurut Nawawi (2005:97),secara garis besar terdapat beberapa dimensi yang dapat dijadikan ukuran kinerja adalah :

1. Tingkat kemampuan kerja

(kompetensi) dalam melaksanakan pekerjaan baik yang diperoleh dari hasil pendidikan dan pelatihan maupun yang bersumber dari pengalaman kerja.

2. Tingkat kemampuan eksekutif dalam memberikan motivasi kerja, agar karyawan sebagai individu bekerja dengan usaha maksimum, yang memungkinkan tercapainya hasil sesuai dengan keinginan dan kebutuhan perusahaan.

Kinerja dan motivasi merupakan dua sisi mata uang yang sulit dipisahkan.

Motivasi merupakan daya penggerak yang mencipatakan kegairahan kerja seseorang, agar mereka mau bekerja sama, bekerja efektif dan terintegrasi dengan segala daya upayanya untuk mencapai kepuasan.

Selain dengan motivasi, salah satu cara untuk meningkatkan kinerja karyawan yaitu melalui peningkatkan kemampuan dan keahlian tenaga kerja dengan pelatihan. Menurut Achmad Darodjat (2015:75), menyatakan bahwa

pelatihan dimaksudkan untuk menyesuaikan tuntutan-tuntutan baru atas sikap, prilaku, ketrampilan dan pengetahuan, dengan program pelatihan diharapkan para pegawai dapat memberikan kontribusi dan prestasi yang optimal sehingga tujuan organisasi dapat tercapai.

Menyadari pentingnya sumber daya manusia bagi kelangsungan dan kemajuan perusahaan,maka selain dengan pelatihan,perusahaan harus memberikan perhatian khusus dan harus dapat bersikap adil atas apa yang telah diberikan sumber daya manusia kepada perusahaan,karena setiap karyawan berhak mendapat penghargaan dan perlakuan yang adil dari pimpinan perusahaan sebagai timbal balik atas jasa yang diberikannya,sehingga hal demikian dapat mendorong para karyawan untuk lebih termotivasi dalam bekerja dan memberikan kinerja yang baik untuk kemajuan perusahaan, alasan inilah pentingnya perusahaan memberikan kompensasi yang sesuai atas kinerja yang telah diberikan karyawan kepada perusahaan.

Dari hasil pengamatan yang dilaksanakan pada PT.Innovative Plastic Packaging Karawang plant pada tahun 2015 dan 2016, mengenai target dan jumlah out put produksi selama tahun tersebut, menunjukan bahwa perusahaan masih belum mencapai target kinerja sesuai dengan yang diharapkan. 
Produktifitas perusahaan meskipun mengalami peningkatan dari tahun 2015 sebanyak 36,47\% menjadi 56,77\% pada tahun 2016, atau peningkatan sebesar 20,30\% akan tetapi keduanya masih jauh dibawah target dan masih termasuk dalam kategori kurang baik. Ini menunjukan bahwa pencapaian kinerja karyawan pada PT.Innovative Plastic Packaging masih rendah dan belum optimal. Hal ini dapat mengindikasikan bahwa pengetahuan, ketrampilan, sikap, dan motivasi kerja karyawan masih rendah dan perlu ditingkatkan.

Pada tinjauan penelitian terdahulu diuraikan beberapa penelitian yang berfokus pada masalah sumberdaya manusia khususnya tentang pengaruh dan hubungan dari pelatihan, kompensasi, motivasi kerja dan kinerja karyawan.

Ahmad Ahid Mudayana (2010), melalui penelitiannya terhadap motivasi kerja karyawan di Rumah Sakit Nur Hidayah Bantul, menyimpulkan bahwa Karyawan akan termotivasi apabila keinginan serta kebutuhan mereka terpenuhi. Terdapat hubungan yang kuat antara motivasi dengan kinerja, semakin tinggi motivasi kerja maka akan semakin baik kinerja yang dihasilkan.

Santoso (2017) dengan penelitiannya mengenai pengaruh pelatihan dan motivasi pada koperasi Agro Niaga Malang, menyimpulkan bahwa pelatihan mempunyai karakteristik yang diinginkan oleh lapangan kerja. Pelatihan membentuk dan menambah pengetahuan seseorang untuk dapat mengerjakan sesuatu yang lebih cepat dan tepat.

Berdasarkan penelitian yang dilakukan oleh Ririvega Kasenda (2013), mengenai kompensasi dan motivasi pengaruhnya terhadap kinerja karyawan pada PT. Bangun wenang di Manado, menyimpulkan bahwa hubungan antara kompensasi dan motivasi dengan kinerja

karyawan sangat kuat. Pemberian kompensasi bagi karyawan harus sesuai dengan peraturan yang berlaku, serta selalu memperhatikan standar dan biaya hidup minimal. Tanpa mengesampingkan asas adil, layak, dan wajar, agar kompensasi yang diberikan kepada masingmasing karyawan sesuai dengan kinerjanya.

Dari beberapa hasil penelitian tersebut diatas, dengan perbedaan lingkungan kerja dan responden yang diteliti, menjadi dasar bagi penulis untuk dapat membuktikan adanya pengaruh atau tidaknya secara signifikan antara pelatihan terhadap motivasi, pengaruh kompensasi terhadap motivasi, pelatihan dan kompensasi terhadap motivasi, pengaruh pelatihan terhadap kinerja karyawan, kompensasi terhadap kinerja karyawan serta pengaruh dari motivasi terhadap kinerja karyawan.

\section{TINJAUAN PUSTAKA Manajemen}

Manajemen merupakan suatu proses untuk mencapai tujuan organisasi

baik sebagai suatu kumpulan pengetahuan yang logis dan sistematis maupun sebagai suatu kreativitas pribadi yang disertai suatu ketrampilan.

AchmadDarodjat (2015:24) mengutip pendapat George R.Terry dalam Principlees of Management memberikan

pengertian sebagai berikut : "management is dintince process consisting of planning, organizing, actuating, and controlling performed to determine and accomplish stated objectives by the use of human being and other resources".

"Manajemen adalah suatu proses yang khas, yang terdiri dari tindakan

perencanaan, pengorganisasian, penggerakan, dan pengendalian yang dilakukan untuk menentukan serta mencapai tujuan yang telah ditentukan 
melalui pemanfaatan sumber daya manusia dan sumber daya lainnya”.

$$
\text { Berkaitan dengan fungsi }
$$

manajemen, berikut disampaikan beberapa fungsi utama manajemen yang dikemukakan oleh GerogeR.Terry dan Leslie W.Rue (2016:9) sebagai berikut :

1. Planning (Perencanaan); Menentukan tujuan-tujuan yang hendak dicapai selama suatu masa yang akan datang dan apa yang harus diperbuat agar dapat mencapai tujuan-tujuan tersebut.

2. Organizing (Pengorganisasian); mengelompokan dan menentukan berbagai kegiatan penting dan memberikan kekuasaan untuk melaksanakan kegiatan-kegiatan tersebut.

3. Staffing (Pengarahan) ; menentukan keperluan-keperluan sumber daya manusia, pengerahan, penyaringan, latihan dan pengembangan tenaga kerja.

4. Motivating (Pemotivasian) ; mengarahkan atau menyalurkan perilaku manusia kearah tujuan.

5. Controlling (Pengendalian); mengukur pelaksanaan dengan

tujuan, menentukan sebab penyimpangan dan mengambil

tindakan korektif bilamana diperlukan.

\section{Manajemen Sumber Daya Manusia}

Prabu Mangkunegara (2015:2)

menyatakan bahwa "Manajemen sumber daya manusia merupakan suatu

perencanaan, pengorganisasian, pengkoordinasian, pelaksanaan, dan pengawasan terhadap pengadaan, pengembangan, pemberian balas jasa, pengintegrasian, pemeliharaan dan pemisahan tenaga kerja dalam rangka mencapai tujuan organisasi." Fungsi manajemen sumber daya manusia adalah untuk mengatur dan mengelola sumber

daya manusia semaksimal dan seefektif mungkin agar diperoleh kinerja yang maksimal.

\section{Pelatihan}

Menurut Samsudin dalam Yusup Hamali (2016: 64),Pelatihan merupakan bagian dari pendidikan. Pelatihan bersifat spesifik, praktis dan segera. Spesifik berati pelatihan berhubungan dengan bidang pekerjaan yang dilakukan. Praktis berarti program pelatihan yang sudah diberikan dapat diimplementasikan. Segera berarti pelatihan pada umumnya dimaksudkan untuk memperbaiki penguasaan berbagai ketrampilan kerja dalam waktu yang relatif singkat. Tujuan Pelatihan

Menurut Hani Handoko (2013:103) mengemukakan bahwa "Ada dua tujuan program pelatihan yaitu : pertama, program pelatihan dilakukan untuk menutup "gap" antara kecakapan atau kemampuan pegawai dengan permintaan jabatan. Kedua, program tersebut diharapkan dapat meningkatkan efisiensi dan efektifitas kerja pegawai dalam mencapai sasaran-sasaran kerja yang telah ditetapkan".

\section{Kompensasi}

Salah satu aspek penting dalam manajemen sumber daya manusia di dalam suatu organisasi adalah aspek

kompensasi. Dengan pemberian kompensasi yang baik dan adil akan meningkatkan tingkat kepuasan kerja dan prestasi kerja karyawan yang akan membantu perusahaan dalam mencapai tujuannya.

Tujuan Pemberian Kompensasi

Tujuan pemberian kompensasi sebagaimana yang disampaikan oleh Malayu Hasibuan (2003:121) pada dasarnya meliputi hal-hal sebagai berikut : 
1. Ikatan kerjasama. Pemberian kompensasi akan menjalin ikatan

kerjasama antara pengusaha dan karyawan.

2. Kepuasan kerja. Prinsip kompensasi memungkinkan karyawan dapat memenuhi kebutuhankebutuhan fisik, status sosial, dan egoistiknya sehingga memperoleh kepuasan kerja.

3. Pengadaan keryawan lebih efektif. Dengan program kompensasi yang baik, maka perusahaan akan mudah dalam pengadaan atau mendapatkan tenaga kerja yang berkualitas.

4. Motivasi. Jika kompensasi yang diberikan cukup besar dan memuaskan, maka manajer akan mudah memotivasi bawahannya.

5. Stabilitas karyawan. Jika program kompensasi cukup adil dan layak serta eksternal konsistensi yang kompetitif, maka stabilitas karyawan akan lebih terjamin karena turn over akan relatif kecil.

6. Disiplin. Dengan program kompensasi yang cukup besar memungkinkan disiplin karyawan akan makin baik, mereka akan menyadari serta mentaati peraturan - peraturan yang berlaku.

7. Pengaruh serikat buruh. Dengan program kompensasi yan baik pengaruh serikat pekerja dapat dihindarkan.

8. Pengaruh Pemerintah. Jika program kompensasi sesuai dengan undang-undang ketenagakerjaan yang berlaku,maka intervensi pemerintah dapat dihindarkan.

\section{Motivasi}

Motivasi merupakan suatu proses psikologis yang mencerminkan interaksi antara sikap, kebutuhan,persepsi, dan keputusan yang terjadi pada diri seseorang. Dan motivasi sebagai proses psikologis timbul diakibatkan oleh faktor didalam diri seseorang itu sendiri yang

disebut instrinsik atau ditimbulkan oleh faktor dari luar yang disebut faktor ekstrinsik.

Fungsi dan Tujuan Motivasi

Menurut Sardiman (2006:85) ada 3 fungsi motivasi yaitu :

1. Mendorong manusia untuk berbuat, jadi sebagai penggerak atau motor yang melepaskan energi.

2. Menentukan arah perbuatan, yaitu kearah tujuan yang hendak dicapai

3. Menyeleksi perbuatan yakni menentukan perbuatan-perbuatan apa yang harus dikerjakan yang serasi guna mencapai tujuan dengan menyisihkan tujuan-tujuan yang tidak bermanfaat bagi tujuan tersebut.

\section{Kinerja}

Kinerja merupakan suatu kondisi yang harus diketahui dan dikonfirmasikan kepada pihak tertentu untuk mengetahui tingkat pencapaian hasil yang dihubungkan dengan visi yang diemban oleh individu atau suatu organisasi dari suatu kebijakan operasional.

\section{Menurut Nanang Fattah dalam}

Achmad Darodjat (2015:113) mengemukakan bahwa kinerja atau prestasi kerja atau penampilan kerja diartikan sebagai ungkapan kemampuan yang didasari oleh pengetahuan, sikap dan ketrampilan dan motivasi dalam menghasilkan sesuatu. Tujuan Penilaian Kinerja

Menurut Simamora (2015:343) pada dasarnya tujuan penilaian kinerja dapat digolongkan ke dalam dua bagian besar yaitu :

1. Tujuan evaluasi, dalam hal ini manajer organisasi memberi penilian kinerja karyawan dengan tujuan diantaranya untuk pengambilan keputusan dalam hal promosi, demosi, kompensasi dan terminasi.

2. Tujuan pengembangan, Tujuan pengembangan ini berguna untuk mengubah perilaku, sikap, keahlian, atau pengetahuan dalam meningkatkan kinerja seorang karyawan di masa yang akan datang. 
Hasil Penelitian Terdahulu Yang Relevan. Pada tinjauan penelitian terdahulu diuraikan beberapa penelitian yang berfokus pada masalah tentang pengaruh dan hubungan dari pelatihan, kompensasi, motivasi kerja dan kinerja karyawan. Sopa martina dan Didin

Syarifuddin (2014) melalui penelitiannya, "pengaruh pelatihan dan pengembangan terhadap motivasi dampaknya terhadap prestasi kerja karyawan di lokawisata

baturaden". Menyimpulkan hasil penelitiannya bahwa variabel pelatihan dan pengembangan terhadap variabel motivasi karyawan obyek wisata lokawisata Baturaden termasuk dalam kategori cukup baik, pelatihan dan pengembangan dapat mempengaruhi motivasi karyawan dalam bekerja.

Rijalu Negash, Shimelis Zhewude dan Rita Magersa dalam journal of business management and account (2014), dengan judul penelitian "The effect of compensation on employee motivation in Jimma University academic staff". Hasil penelitian menunjukan bahwa ada hubungan anatara kompensasi dan komponen-komponennya terhadap motivasi kerja karyawan.

penelitian terdahulu yang telah dilakukan oleh Riyadi, Rido mahfudz (2016), yang berjudul "Pengaruh pelatihan dan kompensasi terhadap kinerja karyawan dengan motivasi sebagai mediasi karyawan PT.PAL Indonesia Persero Divisi kapal perang". Hasil penelitian menunjukan bahwa pelatihan berpengaruh terhadap motivasi karyawan, kompensasi berpengaruh terhadap motivasi karyawan dan motivasi berpengaruh terhadap kinerja karyawan PT.PAL Indonesia (Persero).

Sementara itu hasil penelitian terdahulu yang telah dilakukan oleh Ahmad Ahid Mudayana (2010), dengan judul "Pengaruh motivasi dan beban kerja terhadap kinerja karyawan di Rumah sakit Nur Hidayah Bantul". Hasil penelitian menunjukan terdapat pengaruh faktor motivasi instrinsik dan motivasi ekstrinsik terhadap kinerja karyawan.

penelitian terdahulu yang telah dilaksanakan oleh Eli Yulianti (2015), dengan judul "pengaruh pelatihan terhadap kinerja karyawan Grand Fatma Hotel di Tenggarong Kutai Kartanegara". Hasil penelitian menunjukan bahwa pelatihan berpengaruh signifikan terhadap kinerja karyawan

penelitian terdahulu yang telah dilakukan oleh Usman Fauzi (2014), dengan judul "Pengaruh kompensasi terhadap kinerja karyawan pada PT.Trakindo Utama Samarinda". Hasil penelitian menunjukan bahwa kompensasi finansial dan non finansial berpengaruh positif dan signifikan terhadap kinerja karyawan.

Penelitian lain yang telah dilakukan oleh Lia Fauziah dalam jurnal ilmu

manajemen(2013), dengan judul "Pengaruh motivasi, pelatihan dan kompensasi terhadap kinerja karyawan PT.Nadira Prima Semarang". Hasil penelitian menunjukan bahwa motivasi kerja, pelatihan dan kompensasi berpengaruh secara bersama-sama terhadap kinerja karyawan.

Ada sebagian penelitian dengan hasil yang berbeda dengan beberapa penelitian diatas, Sebagaimana penelitian yang telah dilakukan oleh Edi Pakpahan, Siswidiyanto, Sukanto (2014), dengan judul "Pengaruh pendidikan dan pelatihan terhadap kinerja karyawan (Studi pada Badan Kepegawaian Daerah Kota Malang)". Hasil penelitian menunjukan bahwa pendidikan berpengaruh signifikan terhadap kinerja karyawan dan variabel 
pelatihan tidak berpengaruh signifikan terhadap kinerja karyawan.

Sementara itu penelitian terdahulu yang telah dilakukan oleh Mita Afnita, Mahlia Muis, Fauziah Umar (2014) dengan judul "Pengaruh budaya organisasi dan kompensasi terhadap kinerja karyawan". Hasil penelitian menunjukan bahwa budaya organisasi berpengaruh signifikan terhadap kinerja karyawan, sedangkan kompensasi tidak berpengaruh signifikan terhadap kinerja karyawan. .

Perbedaan dari beberapa hasil penelitian tersebut dimungkinkan karena berbedanya kondisi lingkungan dari responden yang diteliti, bila lingkungan yang diteliti sebagian besar responden berada pada level esteem atau status need (kebutuhan akan penghargaan dan prestise) daripada level physiological needs (kebutuhan fisik) dari teori maslow, maka pelatihan dan kompensasi akan kurang memberikan pengaruh terhadap kinerja dibandingkan dengan motivasi terhadap kinerja mereka.

\section{METODE PENELITIAN}

\section{Obyek dan Metode Penelitian}

Objek penelitian yang menjadi variabel bebas dalam penelitian ini adalah pelatihan dan kompensasi. Sedangkan yang menjadi variabel terikat adalah motivasi kerja dan kinerja karyawan.Sifat penelitian dari penelitian ini adalah bersifat deskriftif dan verifikatif. Sedangkan metode penelitian yang digunakan dalam penelitian ini adalah metode descriptive survey dan metode explanatory survey. Penelitian deskriptif atau explanantory surveyadalah penelitian yang bermaksud menjelaskan kedudukan variabel-variabel yang diteliti serta pengaruh antara satu variabel dengan variabel yang lain.Unit analisis dalam penelitian ini adalah para karyawan pada PT.Innovative Plastic Packaging Karawang Plant. Horizonwaktu dalam penelitian ini adalah crossectional, dimana penelitian dilakukan dalam satu waktu secara serentak.

\section{Definisi Konseptual dan Operasional Variabel Penelitian}

Dalam penelitian ini terdapat tiga variabel yang diteliti, yaitu variabel bebas (Independent Variabel) yang tidak bergantung pada variabel lain. Variabel intervening merupakan variabel antara yang menjadi sebab perubahan atau timbulnya variabel terikat. Dan variabel Terikat (Dependent Variable) yang tergantung pada variabel lain atau variabel yang kondisinya dipengaruhi oleh variabel yang lain.

Untuk menghindari pengertian yang berbeda dari variabel yang digunakan dalam penelitian ini, maka perlu dibuat batasan dari masing-masing variabel sebagai berikut :

\section{a. Variabel Bebas Pelatihan $\left(\mathbf{X}_{1}\right)$}

Pelatihan adalah secara konseptual difokuskan sebagai suatu proses belajar mengajar yang bersipat jangka pendek dengan mempergunakan teknik dan metoda tertentu, dan suatu upaya yang Terencana dari organisasi untuk meningkatkan keterampilan, kemampuan, pengetahuan, sikap dan perilaku kerja seseorang atau sekelompok orang dalam pelaksanaan tugas tertentu dan tugas yang dilakukan sekarang. Skor penilaian yang diperoleh dari jawaban responden Melalui instrument penelitian yang mengukur pelatihan dalam beberapa indicator diantaranta : Penilaian

kebutuhan pelatihan, kesiapan pelatihan, lingkungan belajar, transfer pelatihan, metode pelatihan dan evaluasi program pelatihan. Kemudian dioperasionalisasikan dalam bentuk jawaban terhadap setiap pertanyaan ataupun pernyataan dalam kuesioner yang menyatakan sangat setuju dengan nilai jawaban 5, setuju dengan nilai 4, cukup setuju dengannilai3, 
kurang baik dengan nilai 2, dan sangat tidak setuju dengan nilai jawaban 1 .

b. Variabel Bebas Kompensasi ( $\left.\mathbf{X}_{2}\right)$ Kompensasi secara konseptual

difokuskan sebagai segala sesuatu berupa uang atau bukan uang yang diberikan oleh perusahaan kepada karyawan secara layak dan adil sebagai bagian dari hubungan kepegawaian dan sebagai konsekwensi karena perusahaan telah mempekerjakannya.

Skor penilaian yang diperoleh dari jawaban responden melalui instrument penelitian yang mengukur kompensasi dalam beberapa indikator dimensi

kompensasi finansial langsung, kompensasi finansial tidak langsung, dan kompensasi non finansial. Kemudian dioperasionalisasikan dalam bentuk jawaban terhadap setiap pertanyaan ataupun pernyataan dalam kuesioner yang menyatakan sangat setuju dengan nilai jawaban 5 , setuju dengan nilai 4 , cukup setuju dengan nilai 3 , kurang setuju dengan nilai 2 , dan sangat tidak setuju dengan nilai jawaban 1.

\section{c. Variabel Intervening Motivasi Kerja (Y)}

Motivasi secara konseptual dapat dipandang sebagai fungsi, berarti motivasi berfungsi sebagai proses psikologis, daya penggerak atau sikap mental dari dalam diri individu untuk melakukan aktivitas tertentu dalam mencapai tujuan spesifik tertentu. Motivasi dapat dipandang dari segi proses, berarti motivasi dapat dirangsang oleh faktor luar, yaitu berupa kebutuhan dan keinginan . Motivasi di pandang dari segi tujuan, berarti motivasi identic dengan tujuan dan berbagai sasaran yang telah ditentukan perusahaan yang akan dicapai. Skor penilaian diperoleh dari jawaban responden dari instrument penelitian yang mengukur motivasi kerja dalam beberapa indikator dimensi kebutuhan fisik, kebutuhan rasa aman, kebutuhan sosial, kebutuhan penghargaan, dan kebutuhan aktualisasi diri. Kemudian dioperasionalisasikan dalam bentuk jawaban terhadap setiap pertanyaan ataupun pernyataan dalam kuesioner yang menyatakan sangat setuju dengan nilai jawaban 5, setuju dengan nilai 4 , cukup setuju dengan nilai 3 , kurang setuju dengan nilai 2 , dan sangat tidak setuju dengan nilai jawaban 1 .

\section{d. Variabel Terikat Kinerja Karyawan (z)}

Kinerja karyawan secara konseptual difokuskan sebagai hasil kerja yang dicapai seseorang baik secara kualitas maupun kuantitas selama periode waktu tertentu yang didasari oleh pengetahuan, sikap, ketrampilan dan motivasi dalam

pelaksanaan tugas untuk mencapai sasaran, tujuan, misi dan visi organisasi yang diharapkan.

Skor penilaian yang diperoleh dari jawaban responden melalui instrument penelitian yang mengukur kinerja karyawan dari beberapa indikator dimensi kuantitas pekerjaan (quantity of work), kulaitas pekerjaan (quality of work), pengetahuan pekerjaan (job knowledge), kreatifitas (creativeness), kerjasama (cooperation), ketahanan (dependability), inisiatif (initiative) dan kualitas individu.

Data dan Teknik Pengumpulan Data Sumber data dalam penelitian ini

adalah sumber data primer dan data sekunder. Data primer bersumber dari pemberi data secara langsung yaitu dari kuesioner yang disebarkan kepada karyawan PT.Innovative Plastic Packaging Karawang Plant, sedangkan data sekunder

berupa dokumen atau data administrasi yang berhubungan dengan penelitian.

Tekhnik pengumpulan data primer yang digunakan dalam penelitian ini adalah melalui pengamatan, wawancara, dan penggunaan kuesioner yang di kuantifikasikan dengan menggunakan skala Likert dengan 5(lima) kategori jawaban untuk setiap pertanyaan yang diajukan kepada responden. Skala Likert merupakan penskalaan pernyataan sikap/ pendapat seseorang terhadap sesuatu. Responden diminta mengisi pernyataan dalam skala ordinal berbentuk verbal dalam jumlah kategori tertentu. Dalam penelitian ini cara kuantifikasi dengan rentang nilai 1(satu) sampai dengan 5(lima). 


\section{HASIL DAN PEMBAHASAN}

Penelitian ini menggunakan analisis jalur (path analysis), dengan Jumlah sampel yang diambil sebanyak 80 responden dengan tekhnik sampling jenuh. Metode penelitian yang digunakan dalam penelitian ini dengan menggunakan metode deskriftif dan verifikatif.

\section{Analisis Deskriptif Kinerja Karyawan}

Berdasarkan hasil pengujian data kuesioner atas pernyataan yang ditujukan kepada responden secara deskripsi dari variabel kinerja karyawan (Z) yang terdiri dari 18 pernyataan yang berhubungan dengan pekerjaan selesai tepat waktu,pekerjaan sesuai target yang ditetapka, kepuasan atas hasil kerja, kesesuain tugas dengan perintah kesesuaian tugas dengan prosedur kerja, pengetahuan terhadap tugas, pengetahuan terhadap lingkungan kerja, pengetahuan tentang prosedur kerja,kemampuan menyesuaikan diri dengan kondisi, dapat diandalkan dalam pekerjaan,kerjasama dengan pimpinan, kerjasama dengan rekan kerja,

kemampuan mengambil keputusan, kemampuan menyesuaikan diri, berani mengambil resiko, mencari solusi masalah kerja, kesadaran pada tugas yang dibebankan dan kemampuan dalam berbagai bidang pekerjaan.

dapat dijelaskan bahwa variabel kinerja karyawan $(Z)$ berada pada skala baik dan dapat dideskripsikan dalam rentang skala sebagai berikut :

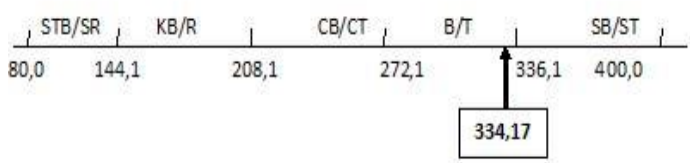

Gambar 1

Rentang Skala Variabel Kinerja Karyawan

(Z)

Gambar 1. diatas menunjukan bahwa variabel kinerja karyawan (Z) berada pada skala baik/tinggi.

\section{Motivasi Kerja}

Berdasarkan hasil pengujian data kuesioner atas pernyataan yang ditujukan kepada responden secara deskripsi dari variabel motivasi kerja (Y) yang terdiri dari 18 pernyataan yang berhubungan dengan bantuan rekan kerja, pergaulan dengan rekan kerja, tenang dan nyaman dalam bekerja, keluarga sumber motivasi, pengakuan dari atasan, sosialisasi dengan lingkungan kerja, jaminan kesehatan, pengembangan diri, keberlangsungan kerja, pemenuhan pangan dan sandang, bermanfaat untuk organisasi, hubungan keluarga, perlindungan kesehatan kerja, keamanan dan kenyamanan kerja, menjadi bagian perusahaan, pemenuhan kebutuhan pokok, pemenuhan pakian seragam dan penghargaan prestasi kerja.

Berdasarkan hasil penelitian dapat dijelaskan bahwa variabel motivasi kerja

(Y) berada pada skala baik dan dapat dideskripsikan dalam rentang skala sebagai berikut : 


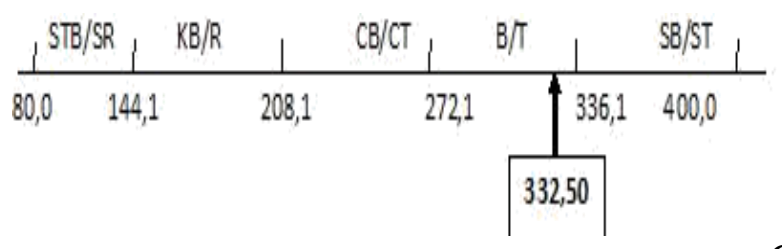

Gambar 2

Rentang Skala Variabel Motivasi Kerja (Y)

Dari gambar 2. diatas menunjukan bahwa variabel motivasi (Y) berada pada skala baik/tinggi.

Pelatihan

Berdasarkan hasil pengujian data kuesioner atas pernyataan yang ditujukan kepada responden secara deskripsi dari variabel pelatihan $\left(\mathrm{X}_{1}\right)$ yang terdiri dari 18 pernyataan yang berhubungan dengan Analisa biay - keuntungan pelatihan, ketrampilan dasar, dukungan teman dan manajer, identifikasi hasil dan desain penelitian, sikap dan motivasi, observasi terhadap orang lain, strategi manajemen pribadi, pelaksanaan dan koordinasi program, umpan balik, metode kelompok, identifikasi tujuan dan hasil pelatihan, praktek pelatihan, analisa kebutuhan tugas, metode hands on, analisa kebutuhan organisasi, metode presentasi, analisa kebutuhan karyawan dan materi pelatihan.

Berdasarkan hasil penelitian dapat dijelaskan bahwa variabel pelatihan $\left(\mathrm{X}_{1}\right)$ berada pada skala baik dan dapat dideskripsikan dalam rentang skala sebagai berikut :

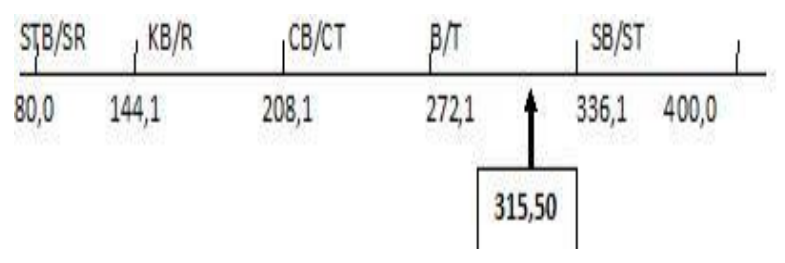

Gambar 3

Rentang Skala Variabel Pelatihan $\left(\mathrm{X}_{1}\right)$

Dari gambar 3.Diatas, menunjukan bahwa variabel pelatihan $\left(\mathrm{X}_{1}\right)$ berada pada skala baik/tinggi.

\section{Kompensasi}

Berdasarkan hasil pengujian data kuesioner atas pernyataan yang ditujukan kepada responden secara deskripsi dari variabel kompensasi $\left(\mathrm{X}_{2}\right)$ yang terdiri dari 18 pernyataan yang berhubungan dengan status kekaryawanan, penentuan gaji berdasarkan kehadiran, upah tambahan, hadiah karyawan berprestasi, upah tambahan lembur, tunjangan hari raya, pujian dari atasan, evaluasi hasil kerja, penyesuaian gaji berdasarkan kebutuhan hidup, status karyawan berdasarkan penilaian, asuransi kesehatan, gaji/upah karyawan sakit, jaminan hari tua/pensiun, bantuan pendidikan, tunjangan kehadiran kerja, pemberian bonus dan gaji/upah.

Berdasarkan hasil penelitian dapat dijelaskan bahwa variabel kompensasi $\left(\mathrm{X}_{2}\right)$ berada pada skala baik dan dapat dideskripsikan dalam rentang skala sebagai berikut :

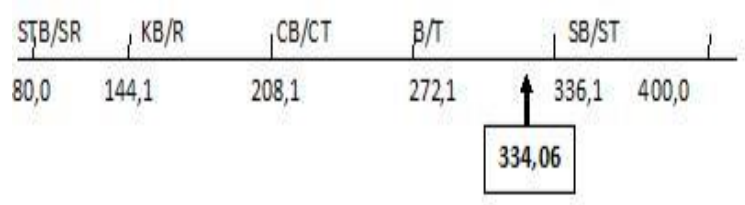

Gambar 4

Rentang Skala Variabel Kompensasi $\left(\mathrm{X}_{2}\right)$

Dari gambar 4. diatas, menunjukan bahwa variabel kompensasi $\left(\mathrm{X}_{2}\right)$ berada pada skala baik/tinggi. 
Analisis Verifikatif dan Uji Hipotesis Analisis jalur (path analysis) dalam penelitian ini akan menjelaskan seberapa besar pengaruh parsial dan simultan dari varibel bebas pelatihan $\left(\mathrm{X}_{1}\right)$ dan kompensasi $\left(\mathrm{X}_{2}\right)$ terhadap variabel motivasi $(\mathrm{Y})$, dan seberapa besar pengaruh variabel motivasi $(\mathrm{Y})$ terhadap variabel terikat kinerja karyawan $(\mathrm{Z})$ serta seberapa besar pengaruh parsial dan simultan variabel bebas pelatihan $\left(\mathrm{X}_{1}\right)$,

kompensasi $\left(\mathrm{X}_{2}\right)$, dan variabel motivasi $(\mathrm{Y})$ terhadap variabel terikat kinerja karyawan (Z).

Beberapa tahapan pada analisa jalur sebagai berikut :

Tahap kesatu; Menentukan diagram jalur berdasarkan paradigma pengaruh variabel sebagai berikut:

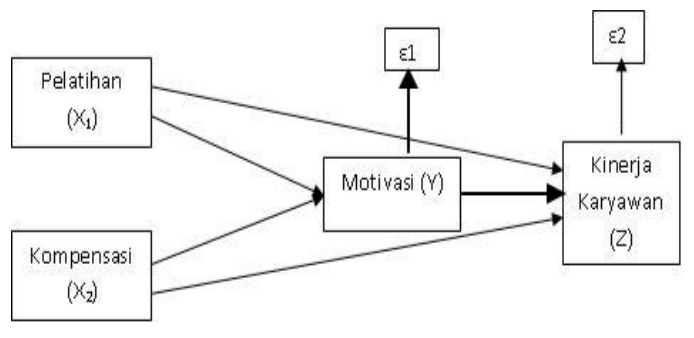

Gambar 5

Diagram Jalur

Diagram jalur di atas terdiri atas dua persamaan struktural, Dimana pelatihan $\left(X_{1}\right)$ dan kompensasi $\left(\mathrm{X}_{2}\right)$ adalah variabel bebas dan kompensasi $(\mathrm{Y})$ serta kinerja karyawan $(\mathrm{Z})$ adalah variabel terikat.

Tahap kedua; Menentukan persamaan struktural sebagai berikut :

Persamaan substruktural 1 (satu) yaitu ;

$Y=\rho \mathbf{x}_{1}+\rho \mathbf{Y x}_{2}+\varepsilon_{1}$

Keterangan :

$\mathrm{Y}=$ Motivasi

$\mathrm{X}_{1}=$ Pelatihan

$\mathrm{X}_{2}=$ Kompensasi

$\varepsilon_{1}=$ Error

Persamaan sub struktural 2 (dua) yaitu :

$\mathbf{Z}=\rho \mathbf{Z X}_{1}+\rho \mathbf{Z X}_{2}+\rho \mathbf{Z Y}_{\mathbf{Y}}+\boldsymbol{\varepsilon}_{2}$

Keterangan :

$\mathrm{Z}=$ Kinerja Karyawan

$\mathrm{X}_{1}=$ Pelatihan

$\mathrm{X}_{2}=$ Kompensasi

$\mathrm{Y}=$ Motivasi $\varepsilon_{2}=$ Error

Tahap ketiga ; Menganalisis dengan menggunakan SPSS terhadap substruktur 1 dan terhadap substruktur 2 berikut resume hasil.

Pengaruh Parsial Dan Simultan Pelatihan $\left(\mathbf{X}_{1}\right)$ Dan Kompensasi $\left(\mathbf{X}_{2}\right)$ Terhadap

Motivasi Kerja (Y). 
Untuk mengetahui pengaruh pelatihan $\left(\mathrm{X}_{1}\right)$ dan kompensasi $\left(\mathrm{X}_{2}\right)$ terhadap motivasi $(\mathrm{Y})$ secara parsial adalah dengan uji t, sedangkan untuk

mengetahui besarnya pengaruh menggunakan angka Beta atau Standarized Coefficient berikut ini:

Tabel 1

Out Put SPSS Pelatihan $\left(\mathrm{X}_{1}\right)$, Kompensasi $\left(\mathrm{X}_{2}\right)$ Parsial Terhadap Motivasi Kerja

(Y)

Coefficients $^{\mathrm{a}}$

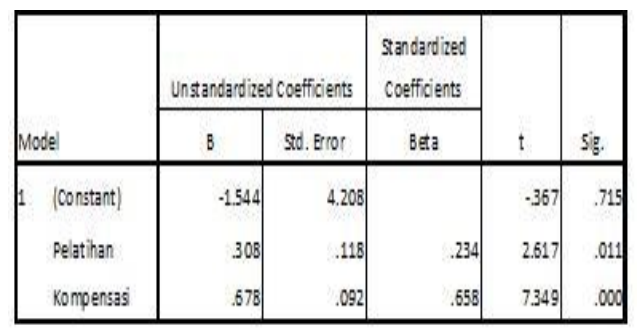

1. Pengaruh pelatihan $\left(X_{1}\right)$ terhadap motivasi (Y)

Hipotesisnya adalah sebagai berikut:

$\mathrm{H} 0$ = Tidak terdapat pengaruh pelatihan terhadap motivasi

$\mathrm{H} 1=$ Terdapat pengaruh pelatihan terhadap motivasi

Kriteria uji hipotesis sebagai berikut:

Jika t hitung > t tabel, maka $\mathrm{H} 0$ ditolak dan $\mathrm{H} 1$ diterima.

Jika t hitung < t tabel, maka H0 diterima dan H1 ditolak.

Berdasarkan hasil perhitungan, diperoleh angka t hitung sebesar $2.617>\mathrm{t}$ tabel sebesar 1.991 (taraf signifikansi 0.05 dan derajat kebebasan $(\mathrm{dk})=\mathrm{n}-2=80-2=78)$. Sehingga H0 ditolak dan H1 diterima, kesimpulan terdapat pengaruh signifikan pelatihan terhadap motivasi kerja. Besarnya pengaruh pelatihan terhadap motivasi sebesar 0.234 yang ditunjukkan dari besarnya nilai $\beta$ dari

penelitian, mengandung arti apabila pelatihan naik/turun 1 (satu) point maka motivasi naik/turun 0.234 point.

\section{Pengaruh parsial kompensasi $\left(\mathbf{X}_{2}\right)$ terhadap motivasi $(\mathbf{Y})$.}

Hipotesisnya adalah sebagai berikut: $\mathrm{H} 0=$ Tidak ada pengaruh kompensasi terhadap motivasi.

H1 = Ada pengaruh kompensasi terhadap motivasi.

Kriteria uji hipotesis sebagai berikut:

Jika t hitung $>\mathrm{t}$ tabel, maka $\mathrm{H} 0$ ditolak dan $\mathrm{H} 1$ diterima.

Jika thitung < t tabel, maka H0 diterima dan H1 ditolak.

Berdasarkan hasil perhitungan, diperoleh angka $t$ hitung sebesar $7.349>\mathrm{t}$ tabel sebesar 1.991 (taraf signifikansi 0.05 dan derajat kebebasan $(\mathrm{dk})=\mathrm{n}-2=80-2=78$ ). Sehingga H0 ditolak dan $\mathrm{H} 1$ diterima, kesimpulan terdapat pengaruh antara kompensasi terhadap motivasi. Besarnya pengaruh kompensasi terhadap motivasi sebesar 0,658 yang ditunjukkan dari besarnya nilai $\beta$ dari penelitian, mengandung arti apabila kompensasi naik/turun 1 (satu) point maka motivasi naik/turun 0.658 point. 


\section{Mengetahui pengaruh simultan pelatihan $\left(X_{1}\right)$ dankompensasi $\left(X_{2}\right)$ terhadap motivasi kerja $(\mathbf{Y})$}

Tabel 2

Out Put SPSS Pelatihan $\left(\mathrm{X}_{1}\right)$, Kompensasi $\left(\mathrm{X}_{2}\right)$ Simultan Terhadap Motivasi Kerja (Y)

a. Predictors: (Constant), Kompensasi, Pelatihan

Model Summary

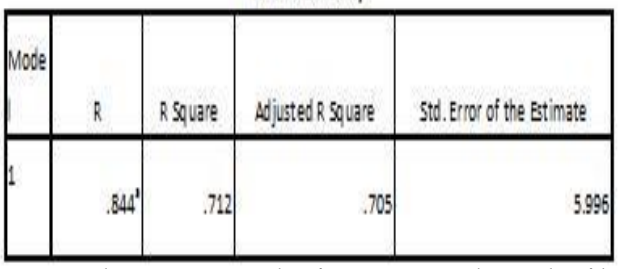

Untuk mengetahui pengaruh pelatihan $\left(\mathrm{X}_{1}\right)$ dan kompensasi $\left(\mathrm{X}_{2}\right)$ terhadap motivasi $(\mathrm{Y})$ secara simultan adalah dari hasil hitung dalam model summary, yaitu angka R Square tersebut. Besarnya angka R Square (r2) adalah 0.712 atau Koefisien Determinasi sebesar $71.2 \%$ yang artinya bahwa pengaruh pelatihan dan kompensasi terhadap motivasi secara simultan adalah 71.2\% sedangkan $28.8 \%$ disebabkan oleh variabel-variabel lain di luar model ini.

Sedangkan untuk mengetahui analisis variansi variabel digambarkan oleh angka-angka dari tabel ANOVA.

Tabel 3

Output SPSS ANOVA Variabel $\mathrm{X}_{1}, \mathrm{X}_{2}$

ANOVA b
\begin{tabular}{|l|r|r|r|c|c|}
\hline Model & Sum of Squares & \multicolumn{1}{|c|}{ df } & Mean Square & F & Sig. \\
\hline 1 Regression & 6849.591 & 2 & 3424.796 & 95.250 & $.000^{\circ}$ \\
Residual & 2768.609 & 77 & 35.956 & & \\
Total & 9618.200 & 79 & & & \\
\hline
\end{tabular}

Dan Y

a.Predictors: (Constant), Kompensasi, Pelatihan

b.Dependent Variable: Motivasi

Sumber : Hasil olah SPSS, 2017 Hipotesisnya adalah sebagai berikut: H0 = Tidak terdapat pengaruh pelatihan dan kompensasi terhadap motivasi.

H1 = Terdapat pengaruh pelatihan dan kompenssi terhadap motivasi. Kriteria:

Jika sig penelitian $<0.05$, atau F hitung

$>\mathrm{F}$ tabel maka $\mathrm{H} 0$ ditolak dan $\mathrm{H} 1$ diterima.

Jika sig penelitian > 0.05, atau F hitung < F tabel maka H0 diterima dan H1 ditolak.

Berdasarkan perhitungan angka signifikan sebesar $0.000<0,05$, dan F hitung 95,20 $>\mathrm{F}$ tabel 2.72, maka $\mathrm{H} 0$ ditolak dan $\mathrm{H} 1$ diterima, artinya terdapat pengaruh signifikan secara

simultan dari variabel pelatihan $\left(\mathrm{X}_{1}\right)$ dan kompensasi $\left(\mathrm{X}_{2}\right)$ terhadap motivasi $(\mathrm{Y})$.

\section{Pengaruh Variabel Motivasi Kerja (Y)}

\section{Terhadap Variabel Kinerja Karyawan $(\mathrm{Z})$}

Pengaruh motivasi kerja terhadap kinerja karyawan, hipotesisnya adalah sebagai berikut:

$\mathrm{H} 0=$ Tidak terdapat pengaruh motivasi kerja terhadap kinerja karyawan .

$\mathrm{H} 1$ = Terdapat pengaruh motivasi kerja terhadap kinerja karyawan.

Kriteria uji hipotesis sebagai berikut:

Jika t hitung > t tabel, maka $\mathrm{H} 0$ ditolak dan $\mathrm{H} 1$ diterima.

Jika t hitung <t tabel, maka HO diterima dan $\mathrm{H} 1$ ditolak. 
Tabel 4

Out Put SPSS Motivasi (Y) Terhadap

Kinerja Karyawan $(\mathrm{Z})$

Coefficients $^{\mathrm{a}}$

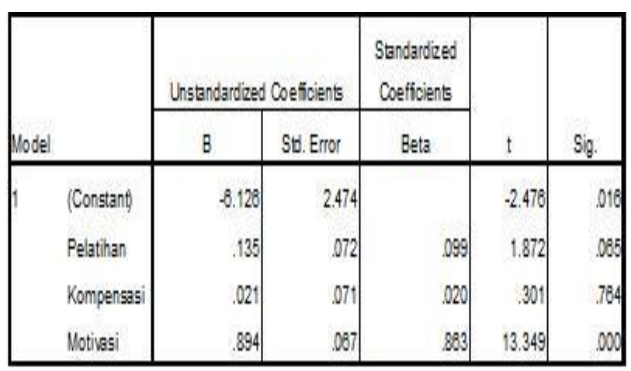

a. Dependent Variable: Kinerja_Karyawan

Sumber : Hasil olah SPSS, 2017

Berdasarkan hasil perhitungan, diperoleh angka t-hitung sebesar $13.349>\mathrm{t}$-tabel sebesar 1.991 (taraf signifikansi 0.05 dan derajat kebebasan $(\mathrm{dk})=\mathrm{n}-2=80-2=78)$. Sehingga H0 ditolak dan H1 diterima, artinya terdapat pengaruh antara motivasi kerja terhadap kinerja. Besarnya pengaruh motivasi kerja terhadap kinerja sebesar 0.863 yang ditunjukkan dari besarnya nilai $\beta$ dari penelitian, mengandung arti apabila motivasi kerja naik/turun 1 (satu) point

pengaruh signifikan antara pelatihan $\left(\mathrm{X}_{1}\right)$ terhadap kinerja karyawan $(\mathrm{Z})$. Besarnya pengaruh pelatihan $\left(\mathrm{X}_{1}\right)$ terhadap kinerja karyawan $(Z)$ sebesar 0,099 dianggap tidak signifikan.

\section{Pengaruh parsial variabel}

kompensasi $\left(X_{2}\right)$ terhadap kinerja karyawan $(Z)$

Hipotesisnya adalah sebagai berikut:

$\mathrm{HO}=$ Tidak terdapat pengaruh

kompensasi terhadap kinerja karyawan

H1 = Terdapat pengaruh kompensasi terhadap kinerja karyawan.

Kriteria uji hipotesis sebagai berikut: Jika t hitung > t tabel, maka H0 ditolak dan H1 diterima.

Jika t hitung <t tabel, maka H0 diterima dan $\mathrm{H} 1$ ditolak.

Berdasarkan hasil perhitungan, diperoleh angka t-hitung sebesar 0,301 < t-tabel sebesar 1,991 (taraf signifikansi 0.05 dan derajat kebebasan $(\mathrm{dk})=\mathrm{n}-2=80-2=78$ ). Sehingga H0 diterima dan $\mathrm{H} 1$ ditolak, artinya tidak terdapat pengaruh antara kompensasi $\left(\mathrm{X}_{2}\right)$ terhadap kinerja karyawan $(\mathrm{Z})$. Besarnya pengaruh kompensasi $\left(\mathrm{X}_{2}\right)$ terhadap kinerja karyawan $(\mathrm{Z})$ sebesar 0.020 yang ditunjukkan dari besarnya nilai $\beta$ dari penelitian dianggap tidak signifikan.

\section{Pengaruh simultan pelatihan $\left(X_{1}\right)$, kompensasi $\left(X_{2}\right)$ dan motivasi $(Y)$ terhadap kinerja karyawan $(\mathbf{Z})$}


Tabel 6

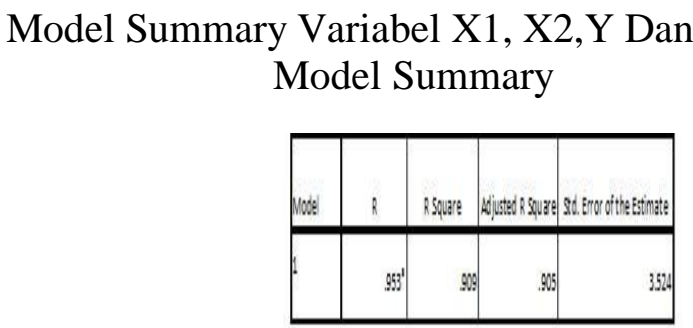

Tabel 6

Model Summary Variabel X1, X2,Y Dan Z Model Summary

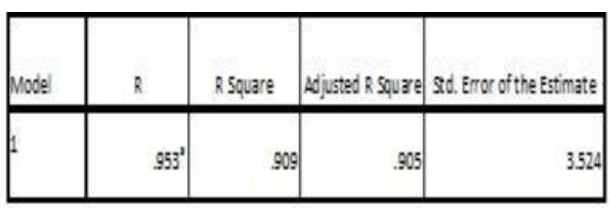

a. Predictors: (Constant), Motivasi, Kompensasi, Pelatihan

Untuk mengetahui pengaruh pelatihan $\left(\mathrm{X}_{1}\right)$, kompensasi $\left(\mathrm{X}_{2}\right)$ dan motivasi kerja

(Y) terhadap kinerja karyawan (Z) secara simultan adalah dari hasil hitung dalam model summary, yaitu angka R Square tersebut. Besarnya angka R Square (r2) adalah 0.909 atau Koefisien

Determinasi sebesar 90,9\% yang artinya bahwa pengaruh pelatihan $\left(\mathrm{X}_{1}\right)$, kompensasi $\left(\mathrm{X}_{2}\right)$ dan motivasi (Y) terhadap kinerja karyawan (Z) secara simultan adalah $90.9 \%$ sedangkan 9.1\% disebabkan oleh variabel-variabel lain di luar model ini.

Sedangkan untuk mengetahui analisis variansi variabel digambarkan oleh angkaangka dari tabel ANOVA.

\section{Tabel 7}

Out Put SPSS ANOVAVariabel $\mathrm{X}_{1}, \mathrm{X}_{2}, \mathrm{Y}$ dan Z

ANOVA $^{\mathrm{b}}$
\begin{tabular}{|l|r|r|r|c|c|}
\hline Model & Sum of Squares & \multicolumn{1}{|c|}{ Df } & Mean Square & F & \multicolumn{1}{c|}{ Sig. } \\
\hline 1 Regression & 9371.540 & 3 & 3123.847 & 251.777 & $.000^{\circ}$ \\
Residual & 942.948 & 76 & 12.407 & & \\
Total & 10314.488 & 79 & & & \\
\hline
\end{tabular}

a. Predictors: (Constant), Motivasi, Pelatihan, Kompensasi

b. Dependent Variable: Kinerja_Karyawan

Sumber : Hasil olah SPSS, 2017

Hipotesisnya adalah sebagai berikut: $\mathrm{H} 0=$ Tidak terdapat pengaruh pelatihan, kompensasi dan motivasi terhadap kinerja karyawan. 
$\mathrm{H} 1$ =Terdapat pengaruh pelatihan,

kompensasi dan motivasi terhadap

kinerja karyawan

Kriteria:

Jika sig penelitian $<0.05$ atau $\mathrm{F}$ hitung

$>\mathrm{F}$ tabel maka $\mathrm{H} 0$ ditolak dan $\mathrm{H} 1$ diterima.

Jika sig penelitian $>0.05$ atau $\mathrm{F}$ hitung $<\mathrm{F}$ tabel maka $\mathrm{H} 0$ diterima dan $\mathrm{H} 1$ ditolak.

Berdasarkan perhitungan angka signifikan sebesar $0.000<0,05$, dan F hitung 251.777 $>$ 2.72, maka $\mathrm{H} 0$ ditolak dan $\mathrm{H} 1$ diterima, artinya terdapat pengaruh signifikan secara simultan dari variabel pelatihan $\left(\mathrm{X}_{1}\right)$, kompensasi $\left(\mathrm{X}_{2}\right)$ dan motivasi $(\mathrm{Y})$ terhadap kinerja karyawan $(\mathrm{Z})$.

Dari hasil analisis diatas, dapat digambarkan diagram jalur (path analysis) variabel pelatihan $\left(\mathrm{X}_{1}\right)$, kompensasi $\left(\mathrm{X}_{2}\right)$ terhadap variabel motivasi $(\mathrm{Y})$ dan terhadap variabel kinerja karyawan(Z) selengkapnya seperti tampak dalam gambar di bawah ini :

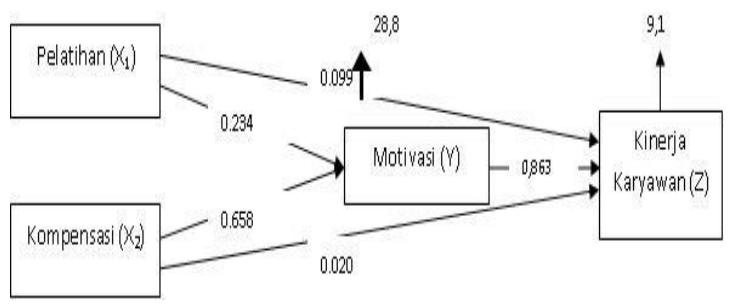

Gambar 6

Diagram Jalur Variabel $\mathrm{X}_{1}, \mathrm{X}_{2}$ Dan Variabel

Y Terhadap Variabel Z

Sumber : Hasil olah data kuesioner.

Sedangkan persamaan struktural

untuk model tersebut sebagai berikut:

Substruktur 1 :

$Y=\rho \mathbf{x}_{1}+\rho \mathbf{Y x}_{2}+\varepsilon_{1}$

$\mathrm{Y}=0.234 \mathrm{X}_{1}+0.658 \mathrm{X}_{2}+0.288$

Keterangan :

$\mathrm{Y}=$ Motivasi Kerja

$\mathrm{X} \quad 1$ = Pelatihan

$\mathrm{X} \quad 2=$ Kompensasi $\varepsilon_{1}=$ Faktor lain Substruktur 2 :

$Z=\rho Z_{1}+\rho Z_{2}+\rho Z_{Y}+\varepsilon_{2}$

$Z=-0.099 X_{1}+0.020 X_{2}+0.863 Z+0,091$

Keterangan :

$\mathrm{Z}=$ Kinerja Karyawan $\mathrm{X}_{1}=$ Pelatihan

$\mathrm{X}_{2}=$ Kompensasi

$\mathrm{Y}=$ Motivasi Kerja $\varepsilon_{2}=$ Faktor lain

Selanjutnya dapat dijelaskan tabel pengaruh pelatihan $\left(\mathrm{X}_{1}\right)$, kompensasi $\left(\mathrm{X}_{2}\right)$ terhadap kinerja karyawan $(\mathrm{Z})$ melaui motivasi $(\mathrm{Y})$.

Tabel 8

Perhitungan Pengaruh Langsung Dan Tidak Langsung Variabel $\mathrm{X}_{1}, \mathrm{X}_{2}, \mathrm{Y}$ dan $\mathrm{Z}$ 


\begin{tabular}{ll|ll}
$\begin{array}{c}\text { Pengaruh } \\
\text { Variabel }\end{array}$ & \multicolumn{2}{c}{$\begin{array}{c}\text { Pengaruh } \\
\text { Langsung }\end{array}$} & \multicolumn{2}{c}{$\begin{array}{c}\text { Melalui } \\
Y\end{array}$} \\
\hline$X_{1} \mathrm{KeY}$ & 0,234 & 0,00 & 0,234 \\
$X_{2} \mathrm{KeY}$ & 0,658 & 0,00 & 0,658 \\
\hline$X_{1} \mathrm{KeZ}$ & 0,099 & 0,202 & 0,301 \\
$X_{2} \mathrm{KeZ}$ & 0,020 & 0,567 & 0,587 \\
$\mathrm{YKeZ}$ & 0,863 & 0,00 & 0,863 \\
\hline
\end{tabular}

sumber : Hasil olah SPSS,2017

Berdasarkan tabel perhitungan pengaruh diatas dapat dijelaskan sebagai berikut :

a. Pengaruh Langsung antar variabel Untuk menghitung pengaruh langsung digunakan formula sebagai berikut:
Pengaruh langsung pelatihan $\left(\mathrm{X}_{1}\right)$ terhadap motivasi $(\mathrm{Y})=0,234$
Pengaruh langsung kompensasi $\left(\mathrm{X}_{2}\right)$ terhadap motivasi $(\mathrm{Y})=0,658$
Pengaruh langsung pelatihan $\left(\mathrm{X}_{1}\right)$ terhadap kinerja karyawan $(Z)=0,099$
Pengaruh langsung kompensasi $\left(\mathrm{X}_{2}\right)$ terhadap kinerja karyawan $(\mathrm{Z})=0,020$

Pengaruh langsung motivasi $(\mathrm{Y})$ terhadap kinerja karyawan $(\mathrm{Z})=0,863$

\section{b. Pengaruh Tidak Langsung}

Untuk menghitung pengaruh tidak langsung digunakan formula sebagai berikut:

$\square$ Pengaruh pelatihan $\left(\mathrm{X}_{1}\right)$ terhadap kinerja karyawan $(\mathrm{Z})$ melalui motivasi $(\mathrm{Y})=(0,234 \mathrm{x}$ $0,863)=0,202$

Pengaruh kompensasi $\left(\mathrm{X}_{2}\right)$ terhadap kinerja karyawan $(\mathrm{Z})$ melalui motivasi $(\mathrm{Y})=(0,658 \mathrm{x}$ $0,863)=0,567$

\section{c. Pengaruh Total}

$\square$ Pengaruh pelatihan $\left(\mathrm{X}_{1}\right)$ terhadap kinerja karyawan $(\mathrm{Z})$ melalui motivasi $(\mathrm{Y})=(0,099+$ $0,202)=0,301$

$\square$ Pengaruh kompensasi $\left(\mathrm{X}_{2}\right)$ terhadap kinerja karywan $(\mathrm{Z})$ melalui motivasi $(\mathrm{Y})=(0,020+$ $0,567)=0,587$

$\square$ Pengaruh motivasi (Y) terhadap kinerja karyawan $(\mathrm{Z})$ sebesar $=0,863$.

Berdasarkan tabel perhitungan pengaruh dapat dijelaskan bahwa pengaruh pelatihan $\left(\mathrm{X}_{1}\right)$ terhadap kinerja karyawan (Z) melaui motivasi

$(\mathrm{Y})=0,202>$ dari pengaruh langsung pelatihan $\left(\mathrm{X}_{1}\right)$ terhadap kinerja

karyawan $(Z)=0,099$. Pengaruh kompensasi $\left(X_{2}\right)$ terhadap kinerja karyawan $(Z)$ melalui motivasi $(\mathrm{Y})=$

$0,567>$ dari pengaruh langsung kompensasi $\left(\mathrm{X}_{2}\right)$ terhadap kinerja

karyawan $(Z)=0,020$. Sehingga motivasi $(Y)$ memiliki pengaruh yang kuat dan signifikan untuk memediasi pelatihan $\left(\mathrm{X}_{1}\right)$ dan kompensasi $\left(\mathrm{X}_{2}\right)$ terhadap kinerja karyawan $(\mathrm{Z})$. 


\section{Kesimpulan dan Saran Kesimpulan}

Dari hasil pengujian yang dilakukan penulis, diperoleh kesimpulan sebagai berikiut :

1. Kinerja karyawan (Z) pada PT.Innovative Plastic Packaging memperoleh rata-rata skor sebesar 334,17, dan bilamana digambarkan dengan rentang skala berada pada skala baik. Artinya bahwa peningkatan kinerja karyawan yang didukung dengan progran pelatihan, kompensasi dan motivasi sudah berjalan dengan baik.

2. Motivasi (Y) pada PT.Innovative Plastic Packaging memperoleh memperoleh skor ratarata sebesar 332,50, dan bilamana digambarkan dengan rentang skala berada pada skala baik. Artinya bahwa motivasi kerja untuk mendorong peningkatkan kinerja karyawan sudah dilaksanakan dengan baik.

3. Pelatihan $\left(\mathrm{X}_{1}\right)$ pada PT.Innovative Plastic Packaging memperoleh skor rata-rata sebesar 315,50, dan bilamana digambarkan dengan rentang skala berada pada skala baik. Artinya program pelatihan sebagai upaya meningkatkan pengetahuan, ketrampilan dan sikap karyawan dalam rangka meningkatkan motivasi dan kinerja sudah dilaksanakan dengan baik.

4. Kompensasi $\left(\mathrm{X}_{2}\right)$ pada PT.Innovative Plastic packaging memperoleh rata-rata skor sebesar 334,06, dan bilamana digambarkan dengan rentang skala berada pada skala baik. Artinya bahwa kompensasi sebagai upaya mendorong motivasi kerja karyawan dalam rangka peningkatan kinerja karyawan telah dilaksanakan dengan baik.

5. Besarnya pengaruh parsial dan simultan pelatihan $\left(\mathrm{X}_{1}\right)$ dan kompensasi $\left(\mathrm{X}_{2}\right)$ terhadap motivasi kerja (Y).

iterima. Kesimpulannya terdapat pengaruh signifikan dari variabel pelatihan $\left(\mathrm{X}_{1}\right)$ dan kompensasi $\left(\mathrm{X}_{2}\right)$ secara simultan terhadap motivasi kerja $(\mathrm{Y})$. Adapun besaran pengaruh simultan dari variabel pelatihan $\left(\mathrm{X}_{1}\right)$ dan kompensasi $\left(\mathrm{X}_{2}\right)$ terhadap motivasi kerja $(\mathrm{Y})$ sebesar $71,2 \%$, ini berarti bahwa pelatihan dan kompensasi secara bersama dapat menjelaskan perannya dalam meningkatkan motivasi kerja sebesar 71,2\%.

6. Besarnya pengaruh motivasi kerja (Y) terhadap kinerja karyawan (Z).

Berdasarkan hasil perhitungan, diperoleh angka t-hitung sebesar $13.349>$ t-tabel sebesar 1.991 (taraf signifikansi 0.05 dan derajat kebebasan $(\mathrm{dk})=\mathrm{n}-2=80-2=78$ ). Sehingga $\mathrm{H} 0$ ditolak dan $\mathrm{H} 1$ diterima. Kesimpulan terdapat pengaruh signifikan antara motivasi kerja (Y) terhadap kinerja karyawan $(\mathrm{Z})$. Adapun besaran pengaruh variabel motivasi kerja (Y) terhadap kinerja karyawan (Z) sebesar 86,3\%, ini berarti bahwa motivasi kerja dapat menjelaskan perannya dalam meningkatkan kinerja karyawan sebesar $86,3 \%$.

7. Besarnya pengaruh parsial dan simultan pelatihan $\left(\mathrm{X}_{1}\right)$, kompensasi $\left(\mathrm{X}_{2}\right)$ dan motivasi $(\mathrm{Y})$ terhadap kinerja karyawan $(\mathrm{Z})$.

a. Pengaruh parsial pelatihan $\left(\mathrm{X}_{1}\right)$ terhadap kinerja karyawan $(\mathrm{Z})$.

Berdasarkan hasil perhitungan, diperoleh angka t-hitung sebesar $1.872<$ dari t-tabel sebesar 1.991 (taraf signifikansi 0.05 dan derajat kebebasan $(\mathrm{dk})=\mathrm{n}-2=80-2=78)$. Sehingga H0 diterima dan H1 ditolak. Kesimpulan tidak terdapat pengaruh parsial yang signifikan

antara pelatihan $\left(\mathrm{X}_{1}\right)$ terhadap kinerja karyawan $(\mathrm{Z})$.

b. Pengaruh parsial kompensasi $\left(\mathrm{X}_{2}\right)$ terhadap kinerja karyawan $(\mathrm{Z})$.

Berdasarkan hasil perhitungan, diperoleh angka t-hitung sebesar 0,301 < t-tabel sebesar 1,991 (taraf signifikansi 0.05 dan derajat kebebasan $(\mathrm{dk})=\mathrm{n}-2=80-2=78$ ). Sehingga H0 diterima dan $\mathrm{H} 1$ ditolak. Kesimpulan tidak terdapat pengaruh signifikan antara kompensasi $\left(\mathrm{X}_{2}\right)$ terhadap kinerja karyawan $(\mathrm{Z})$.

c. Pengaruh simultan pelatihan $\left(\mathrm{X}_{1}\right)$, kompensasi $\left(\mathrm{X}_{2}\right)$ dan motivasi kerja (Y) terhadap kinerja karyawan (Z). 
Berdasarkan perhitungan angka signifikan sebesar $0.000<0,05$, dan F hitung 251.777 $>$ 2.72, maka H0 ditolak dan $\mathrm{H} 1$ diterima. Kesimpulan terdapat pengaruh signifikan secara simultan dari variabel pelatihan $\left(\mathrm{X}_{1}\right)$, kompensasi $\left(\mathrm{X}_{2}\right)$ dan motivasi $(\mathrm{Y})$ terhadap kinerja karyawan $(\mathrm{Z})$. Adapun besaran pengaruh simultan dari variabel pelatihan $\left(\mathrm{X}_{1}\right)$ dan kompensasi $\left(\mathrm{X}_{2}\right)$ serta motivasi kerja $(\mathrm{Y})$ terhadap kinerja karyawan $(\mathrm{Z})$ sebesar 90,9\%, ini

berarti bahwa pelatihan, kompensasi dan motivasi kerja secara bersama dapat menjelaskan perannya dalam meningkatkan kinerja karyawan sebesar 90,9\%.

\section{Saran}

Kinerja, motivasi, pelatihan dan kompensasi pada PT.Innovative Plastic Packaging meskipun secara umum berada pada skala yang baik, namun berdasarkan hasil penelitian dimana terdapat indikator hasil responden yang memperoleh skor yang rendah yaitu kepuasan atas hasil

kerja, penghargaan prestasi kerja,materi pelatihan dan bonus keuntungan perusahaan, sehingga disarankan kepada perusahaan untuk memberikan perhatian secara khusus terhadap beberapa hal tersebut dengan menerapkan berbagai program dan kebijakan yang dapat meningkatkan kinerja karyawan.

2. Dalam penelitian ini besarnya pengaruh pelatihan $\left(\mathrm{X}_{1}\right)$, kompensasi $\left(\mathrm{X}_{2}\right)$ dan motivasi (Y) terhadap kinerja karyawan (Z) secara simultan adalah 90.9\% sedangkan $9.1 \%$ disebabkan oleh variabel-variabel lain di luar model. Oleh karena itu disarankan kepada para peneliti selanjutnya untuk melakukan penelitian yang

lebih komprehensif terhadap

variabel-variabel lain yang sesungguhnya dapat mempengaruhi kinerja karyawan.

\section{DAFTAR PUSTAKA}

Arep, Ishak dan Tanjung, Hendri . 2003. Manajemen Sumber Daya Manusia.

Jakarta: Universitas Trisakti.

Darodjat, Tubagus Achmad. 2015. Konsep-konsep Dasar Manajemen Personalia Masa

Kini. Cetakan Kesatu. Penerbit PT.Refika Aditama,

Bandung

Fahmi, Irham. 2016. Manajemen Sumber Daya Manusia, Teori dan Aplikasi. Cetakan Kesatu.

Penerbit Alfabeta, Bandung.

Gomes, Faustino Cardoso. 2003. Manajemen Sumber Daya Manusia. Penerbit CV.Andi Offset, Yogyakarta.

Hamali, Arif Yusuf. 2016. Pemahaman Manajemen Sumber Daya Manusia Strategi

Mengelola Karyawan. Cetakan Pertama. Penerbit CAPS (Center for Academic Publishing

Service), Jakarta

Handoko, Hani. 2013. Manajemen Personalia \& Sumber Daya Manusia. Edisi Kedua, Cetakan Kedua puluh. Penerbit BPFE-Yogyakarta.

Hasibuan, Malayu S.P. 2016. Manajemen, Dasar, Penegertian, Dan Masalah. Edisi Revisi. Cetakan ketujuh. Penerbit PT.Bumi Aksara, Jakarta.

Hasibuan, Malayu S.P. 2016. Organisasi \& Motivasi, Dasar Peningkatan Produktivitas. Cetakan Kesembilan. Penerbit PT.Bumi Aksara, Jakarta 
Kadarisman. 2014. Manajemen Kompensasi. Cetakan Ke-2. Penerbit PT.Raja Grafindo Persada, Jakarta.

Kaswan. 2013. Pelatihan dan Pengembangan Untuk Meningkatkan Kinerja SDM. Cetakan Kedua.Penerbit Alfabeta, Bandung.

Mangkunegara, A.A.Anwar Prabu. 2013. Manajemen Sumber Daya Manusia Perusahaan, Cetakan ke-11. Penerbit PT.Remaja Rosda Karya, Bandung

Mangkunegara, A.A.Anwar Prabu. 2015. Manajemen Sumber Daya Manusia Perusahaan, Cetakan kedua belas. Penerbit PT.Remaja Rosda Karya Offset, Bandung.

Moekijat. 2010. Manajemen Sumber Daya Manusia. Cetakan Kesembilan. Penerbit CV.Mandar Maju, Bandung.

Mondy, R. Wayne; Noe, Robert M. 2005.

Human Resources Management. International Edition. South Western Publishing:Ohio.

Nawawi, Hadari. 2005. Manajemen Sumber Daya Manusia Untuk Bisnis Yang Kompetitif. Cetakan Keenam. Penerbit Gadjah Mada University Press, Yogyakarta.

Rivai, Veithzal. 2004, Manajemen Sumber Daya Manusia Untuk Perusahaan Dari Teori ke Praktik. Penerbit Rajagrafindo Persada, Jakarta

Sadili Samsudin, 2006. Manjemen Sumber Daya Manusia.Penerbit : CV Pustaka Seti

Santoso. 2017. Pengaruh Pelatihan dan Motivasi terhadap Kinerja karyawan Koperasi Agro Niaga Jaya Abadi Unggul Jabung Malang. Jurnal Warta Ekonomi, Vol.7, No.17 Februari 2017.

Simamora, Henry. 2015. Manajemen Sumber Daya Manusia. Edisi III. Cetakan kelima. Bagian Penerbitan Sekolah Tinggi Ilmu Ekonomi YKPN.

Sugiyono. 2012. Metode Penelitian Kuantitatif kualitatif dan $R \& D$. Cetakan Ke-17. Penerbit Alfabeta, Bandung.

Suharyadi dan Purwanto S.K. (2009). Statistika Untuk Ekonomi dan Keuangan Modern. Jakarta: Salemba Empat

Sutrisno, Edy. 2016. Manajemen Sumber Daya Manusia. $\quad$ Cetakan ke-8. Penerbit Prenadamedia Group, Jakarta.

Sri Wiludjeng S.P, 2007. Pengantar Manajemen, Graha Ilmu: Yogyakarta.

Suwatno dan Donni Juni Priansa 2014, Manajemen SDM dalam Organisasi Publik dan Bisnis, Penerbit Bandung:Bandung.

Terry, George R., Rue, Leslie W. 2016. Dasar-Dasar Manajemen. Cetakan Kedelapan. Penerbit Sinar Grafika Offset. Jakarta. 
Uno, B. Hamzah.2012.Teori Motivasi \& Pengukurannya. Jakarta ; Bumi Aksara.

\section{Peraturan, Kebijakan, dan Buku pedoman}

1. Undang-Undang Republik Indonesia Nomor 13 Tahun 20003, tentang Ketenagakerjaan.

2. Peraturan Menteri Tenaga Kerja dan Transmigrasi Republik Indonesia Nomor 8 Tahun 2014, Tentang Pedoman Penyelenggaraan Pelatihan Berbasis Kompetensi.

3. Buku Pedoman Penulisan Tugas Akhir Mahasiswa Program Pasca Sarjana UNSIKA 
